\title{
排気脈動流による熱伝達に関する研究
}

和佐田 信 $* 1$, 遠藤 正樹 $* 2$

\section{A study on heat transfer by pulsation of exhaust flow}

\author{
Makoto WASADA*1 and Masaki ENDO*2 \\ ${ }^{* 1}$ Graduate School of Science and Engineering, Tokyo Denki University \\ Ishizaka, Hatoyama, Hiki, Saitama 350-0394, Japan \\ ${ }^{* 2}$ School of Science and Engineering, Tokyo Denki University \\ Ishizaka, Hatoyama, Hiki, Saitama 350-0394, Japan
}

\section{Received 28 March 2014}

\begin{abstract}
In recent years, the number of cars and motorcycles has increased around the world and now reached more than a billion. The environmental pollution is caused by the traffic emissions, being critical problem. As one of the countermeasures, higher and higher level standards of emissions have been defined in developed countries. A catalytic converter is one of the most important parts of vehicles' emissions control system, its operating temperature being very high. Vehicles emit most of their pollution during the first a few minutes of engine operation before the catalytic converter has warmed up sufficiently to be effective. Therefore, this study focuses on heating the converter up to the operating temperature, using wave phenomena formed in the exhaust pipe. A real automotive exhaust pipe is modelled as a straight pipe with an obstacle having honeycomb structure, instead of the catalytic converter. A pulsating flow is generated in the pipe using a rotary valve of which opening area changes with time corresponding to that of the exhaust port in a real engine. The pressure histories along the pipe and the temperature in the obstacle are measured. Analyzing the measurement data, the formation of shock is found to play an important role in the temperature rise of the obstacle. Furthermore, the relation is discussed between the wave phenomena and the heat transfer to the obstacle.
\end{abstract}

Key words : Compressible flow, Shock wave, Pulsation, Heat transfer, Catalyzer

\section{1. 研究背景および目的}

近年, 自動車および二輪車の全世界の保有台数は 10 億台を超え, それに伴い環境污染が深刻化し先進国を中心 により一層高い水準の排気ガス規制が定められている。この問題の対策として電気自動車が実用化に至ったが，航 続距離や充電時間等の問題から未だ化石燃料によって動力を得る内燃機関自動車が主流となっている.そのため, 内燃機関自動車に対して, 依然として排気ガス中の有害物質の低減や, 燃費向上などの取り組みへの要求が強まっ ている.

内燃機関の排気ガス浄化システムの中で，古くより使用されてきた装置に触媒が挙げられる．触媒とは，排気 ガス中に含まれる有害物質を無害な物質に変える装置である.この働きは, 触媒が約 $300{ }^{\circ} \mathrm{C}$ 以上の決められた温 度範囲にあるときのみ実現できるが, 冷間始動時の触媒温度は低く, 触媒の早期加熱システムの研究が必要とさ れている. そのため, 触媒の昇温特性の研究 (馬場他, 1995) や, 排気ガス温度の上昇を目的とした, 排気系シス

No. 14-00180 [DOI: 10.1299/transjsme.2014fe0300]

*1 正員, 東京電機大学大学院理工学研究科デザイン工学専攻（干350-0394 埼玉県比企郡鳩山町石坂）

*2 正員, 東京電機大学理工学部電子・機械工学系

E-mail of corresponding author: tdu12rmk26@outlook.jp 
テムの最適化に関する研究 (石谷他, 2005) が行われている. また, シミュレーションによる排気系形状の最適化 に関する研究 (金崎他, 2001) や, 圧力損失低減を目的とした触媒の流動特性に関する研究 (平田他, 2007) が行わ れてきた。

本研究では, 自動車触媒の温度による浄化特性に着目し, 管内に誘起された脈動流が触媒の温度にどのような 影響をもたらすかを議論する。

\begin{tabular}{|c|c|c|c|}
\hline & & 号 & \\
\hline$a$ & : 大気温度から算出した音速 & $s$ & : エントロピ \\
\hline$D$ & : 供試管の内径 & $t$ & : 時間 \\
\hline$f$ & : 脈動周波数 & $\Delta t_{i}$ & : 干渉時間 \\
\hline$I_{p}$ & : 無次元圧力波強さ & $T_{i n}$ & : 流体の主流温度 \\
\hline$L$ & : 供試管の長さ & $T_{r e f}$ & : 基準温度 \\
\hline$n$ & : ロータリーディスクの回転数 & $T_{w}$ & : 障害物の壁面温度 \\
\hline$N$ & : 障害物の格子数 & $T_{0}$ & : 高圧タンク内温度 \\
\hline$p$ & : 測定圧力 & $T_{7}$ & : 測定温度 \\
\hline$p_{\text {atm }}$ & : 大気圧 & $\Delta T$ & : 上昇温度 \\
\hline$p_{0}$ & : 高圧タンク内圧力 & $u$ & : 平均流速 \\
\hline$P$ & : 衝撃波の強さ & $\alpha$ & : 平均熱伝達率 \\
\hline $\operatorname{Pr}$ & : プラントル数 & $\theta$ & : ロータリーディスクの回転角 \\
\hline$q$ & : 熱流束 & $\kappa$ & $:$ 比熱比 \\
\hline$R$ & : 気体定数 & $\tau$ & : ロータリーディスクの開口周期（脈動周期） \\
\hline$R e_{d}$ & : レイノルズ数 & $\psi$ & : ロータリーバルブの開口断面積比 \\
\hline
\end{tabular}

\section{2. 実験装置および方法}

本実験装置は, 内燃機関の排気系内部の流れ場の再現を目的に設計されている. 本研究では, 実機を考慮した うえで普遍的なモデル化を行うため, 構成は排気バルブを 1 つ, 排気管は分岐や集合が存在しない単純直管とし た。また，実機における触媒による圧力損失を再現するために，触媒を再現した障害物を供試管内に設置した。

\section{$2 \cdot 1$ 配管系}

図 1 に配管系統図を示す.本実験で使用した脈動流発生装置は防音室内に設置されており，それ以外の装置はす ベて別室に設置されている. 本実験で用いた作動流体は空気である. 空気は 2 台のコンプレッサによって圧縮され た後に，エアードライヤで除湿され，サージタンクに供給され定常流となる．定常流となった圧縮空気は，オー ダリムーバルフィルタとオイルミストセパレータを通過し, 空気中の微粒子と油分を取り除かれた後に, 脈動流 発生装置の高圧タンクへと供給される.このとき, 高圧タンク内の圧力は 2 つのバルブによって $0.55 \mathrm{Mpa}$ まで調 節することができる，また，調節する際に不要となった圧縮空気は，サイレンサによって消音された後に大気へ と放出される.

\section{$2 \cdot 2$ ロータリーバルブ}

本研究ではディスク型のロータリーバルブを使用しており, それはケーシングとロータリーディスクから構成さ れている. 図 2 にロータリーディスクの概要図を示す。ロータリーディスクは厚み $12 \mathrm{~mm}$, 直径 $260 \mathrm{~mm}$ であり,

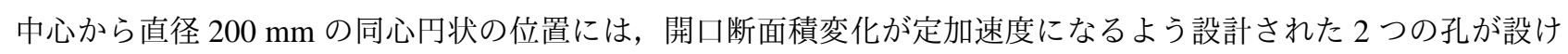
られている．ロータリーディスクが回転することで, ディスク上の孔とケーシングに設けられた直径 $13 \mathrm{~mm}$ の が重なり脈動流が発生する. ロータリーバルブの開口断面積比 $\psi$ は実機の排気バルブの開口断面積比に相当する. ロータリーディスクが 1 回転したときの, 開口断面積比 $\psi$ の変化を図 3 に示す. 図の横軸はロータリーディスク の回転角 $\theta \mathrm{rad}$ を示し, 縦軸はロータリーバルブの開口断面積比 $\psi$ を示している. 図のように, ロータリーバルブ の開口断面積比は周期的に変化する.ロータリーディスクは回転数 $4500 \mathrm{rpm}$ まで回転させることができる.また, 
ロータリーディスクの中心軸にはロータリーエンコーダが設置されており, トリガ信号を出力することができる. ロータリーディスク上には 2 箇所の孔が設けられているため, ディスク 1 回転に対し 2 周期分の脈動流が供試管 内に生じる。ロータリーディスクの開口時間は $1 / 3$ 周期である.

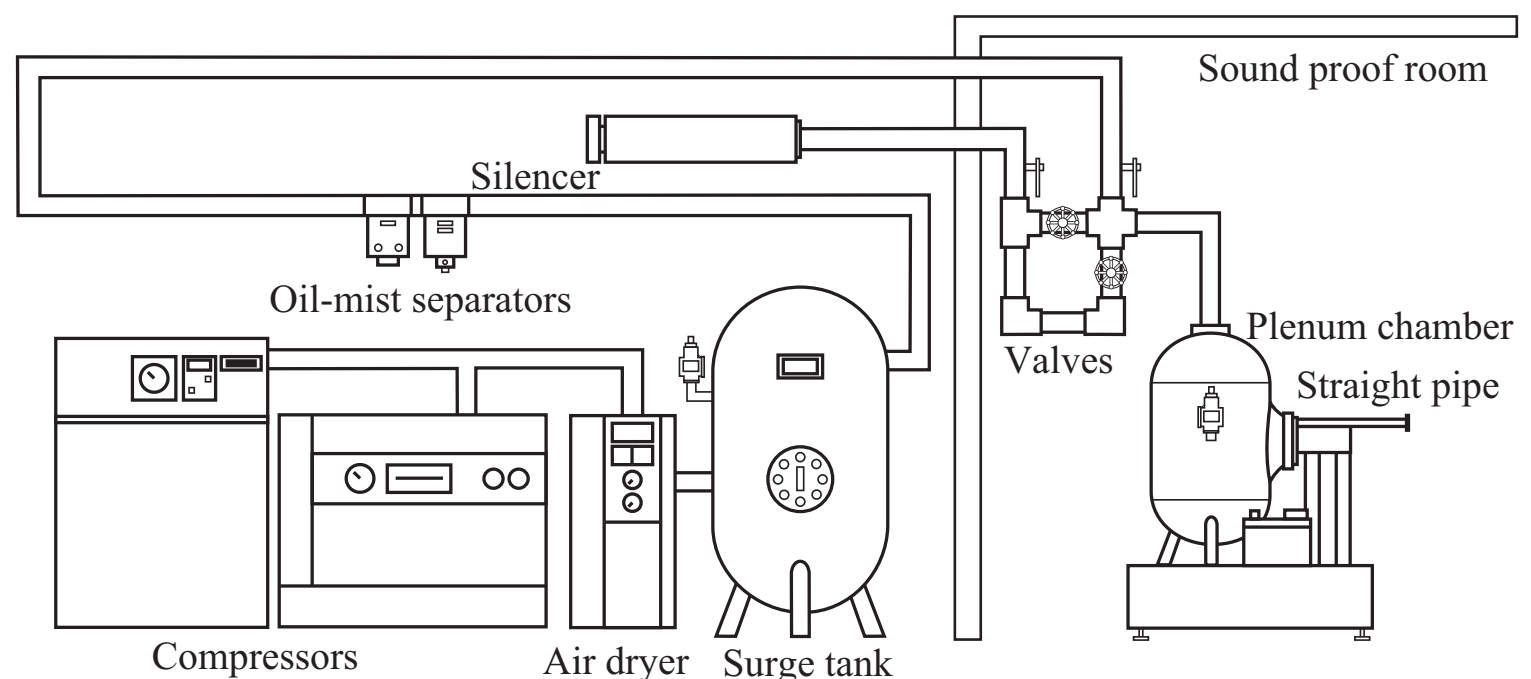

Fig. 1 Piping system. Compressed air is supplied into a pulsating-flow generator in soundproof room through a surge tank and oil-mist separator.

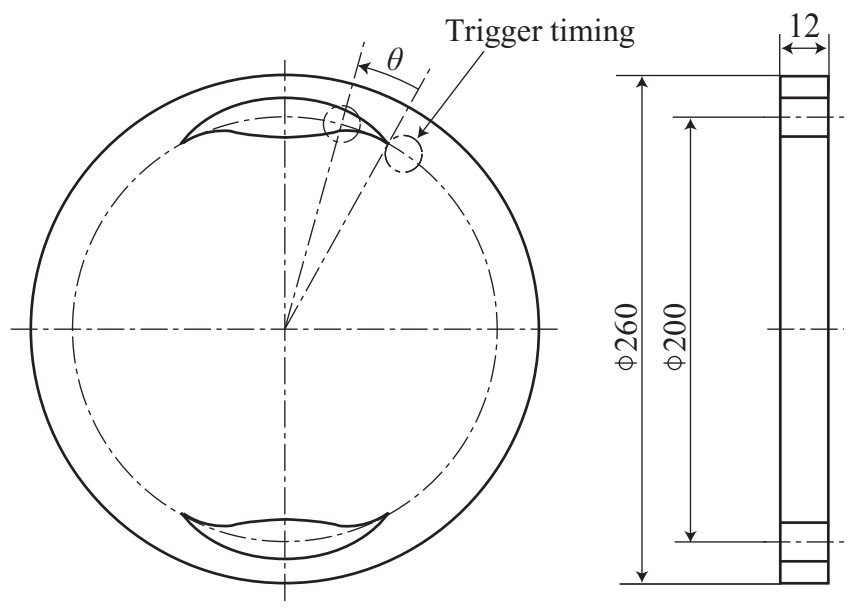

Dimensions in $\mathrm{mm}$

Fig. 2 Geometry of rotary disc. The disk is driven by a motor ranging from $500 \mathrm{rpm}$ to $4500 \mathrm{rpm}$.

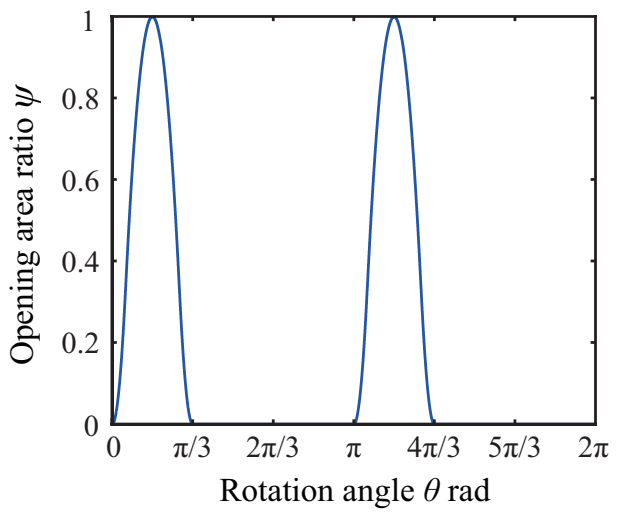

Fig. 3 Opening area ratio of rotary valve. The opening area ratio is designed to be equivalent to that of an exhaust port of 4cycle reciprocating engine with a constant acceleration cam.

\section{$2 \cdot 3$ 供試管}

図 4 に供試管と障害物の概要図を示す。この供試管は，内径 $D=13 \mathrm{~mm}$ ，長さ $L=1100 \mathrm{~mm}$ である. 供試管の側 面には, 圧力測定孔がロータリーディスクから $100 \mathrm{~mm}$ の等間隔に 10 箇所設けられ, 圧力変換器を取り付けるこ とで，管内の静圧を測定することができる。また，測定孔 7 番には温度測定孔が設けられている． L=650 mm の 位置には，触媒を再現した障害物が取り付けられている．触媒の断面形状は四角形のハニカム構造が広く用いら 
れている，管内波動現象は開口断面積率および流体摩擦に強く依存し (Endo and Iwamoto, 1991), 触媒の断面形状 による影響は少ないと考えられる. よって, 障害物は供試管の制約から一辺 $3.2 \mathrm{~mm}$ の正三角形のハニカム構造と し，セラミック型とメタル型の触媒 (古濱，2011) を参考に開口断面積率 80.8 \%で設計した。障害物中央には温度 測定用の隙間が $2 \mathrm{~mm}$ 設けられ, 温度測定孔より熱電対をこの隙間に挿入することで, 障害物に流入した空気温度 の測定を行うことができる.

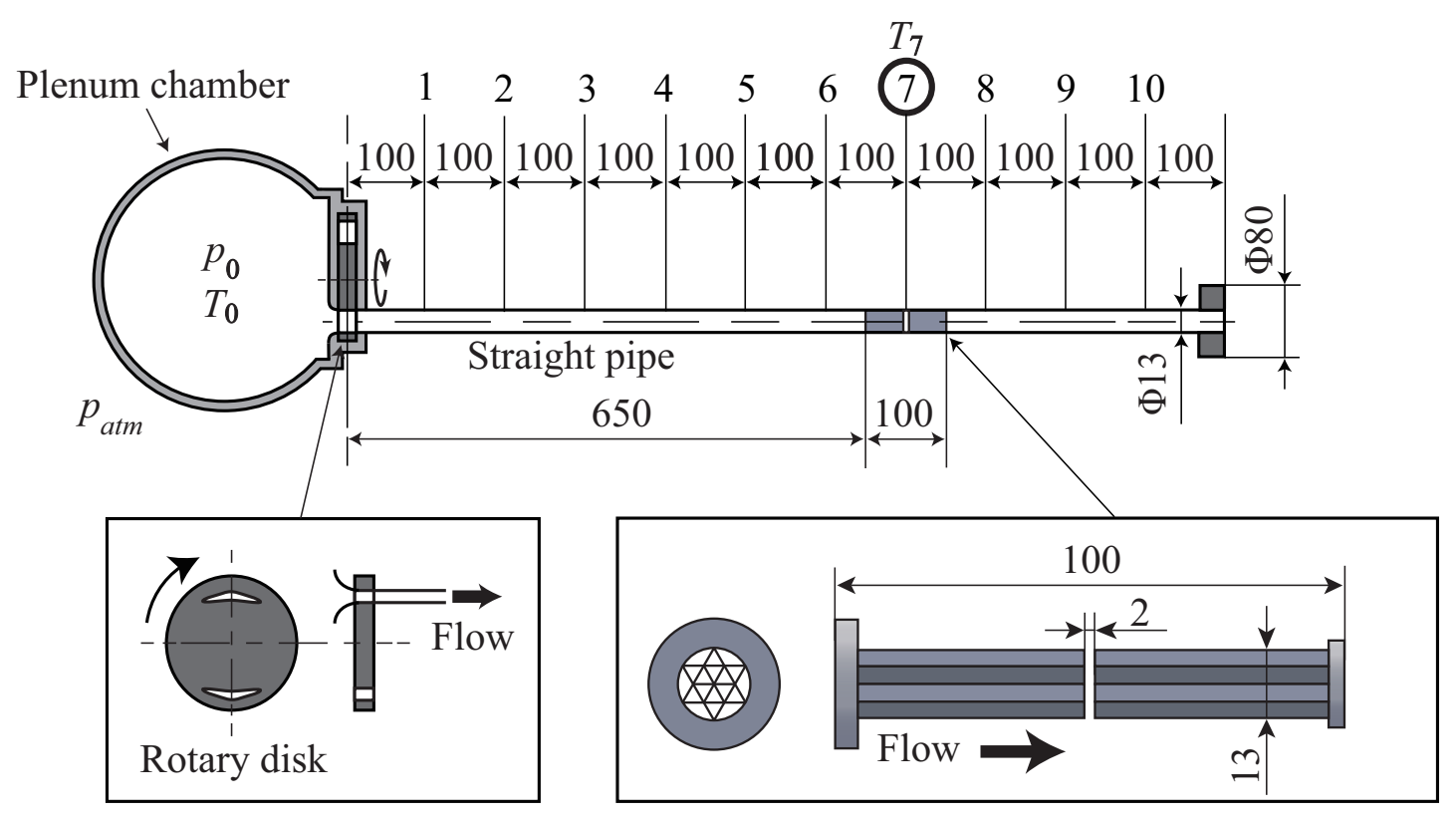

Dimensions in $\mathrm{mm}$

Fig. 4 Geometry of exhaust pipe. The rotary valve is installed between a plenum chamber and a straight pipe. There are 10 stations for pressure measurement along the pipe. An obstacle having honeycomb structure is located at $650 \mathrm{~mm}$ downstream of the rotary valve.

\section{$2 \cdot 4$ 実験方法}

本研究では, 管内に生じる脈動流と障害物近傍の温度との関係を明らかにするために，供試管内の圧力測定お よび温度測定を行った。

供試管内の圧力測定では, 管内の静圧を測定するために半導体小型圧力変換器, 直流増幅器, $\mathrm{AD}$ ボード, ロー タリーエンコーダの 4 種類の機器を使用した. 圧力変換器から出力される電気信号は直流増幅器によって増幅さ れ, 12 bit 分解能の $\mathrm{AD}$ ボードへ出力される. 圧力変換器の 1 次共振周波数は $40 \mathrm{kHz}$ であり, $\mathrm{AD}$ ボードのサン プリング周波数は供試管内を衝撃波が通過することを考慮して $312.5 \mathrm{kHz}$ としている．ロータリーディスクが開孔 する瞬間に合わせて測定開始のトリガ信号を出力するよう，ロータリーエンコーダは設置されている.

障害物近傍の流体温度の測定を行うために, 線径 $0.32 \mathrm{~mm}$ の $\mathrm{T}$ 型熱電対を測定孔 7 番に挿入した。この測定孔 で測定された温度を $T_{7}$ とする．また，供試管内の温度測定と同時に，脈動流発生装置の高圧タンク内温度の測定 を行った．測定された高圧タンク内温度を $T_{0}$ とする．測定は，ロータリーディスクの回転数等の測定条件を目標 值に設定し，10 分間経過した後に， 1 分毎に 5 分間行う。この平均值を温度測定の結果とした。

測定条件は, 高圧タンク内圧力 $p_{0}$ と大気圧 $p_{a t m}$ の比を $p_{0} / p_{a t m}=3.0,3.5,4.0$ のもと, ロータリーディスクの 回転数 $n$ を $500 \mathrm{rpm}$ から $4500 \mathrm{rpm}$ の範囲で, $500 \mathrm{rpm}$ 刻みとした. また, 回転数 $n=500 \mathrm{rpm}$ から $4500 \mathrm{rpm}$ の範囲 の脈動周波数 $f$ は, $f=67 \mathrm{~Hz}$ から $600 \mathrm{~Hz}$ となる. 


\section{3. 排気脈動流による熱伝達}

排気管内を伝ぱする圧力波は，伝ぱの過程で衝撃波へと遷移することが知られている．本実験装置においても， 障害物を取り外した長さ $L=1000 \mathrm{~mm}$ の供試管において, 管内を伝ぱする圧力波は衝撃波へ遷移することが確認さ れている (木村, 岩本, 2001).

図 5 に，供試管内の代表的な圧力変化を示す。圧力波は供試管の下から上に伝ぱするものとする．圧力波形の

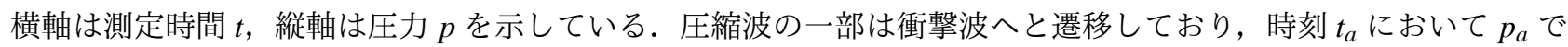
あった圧力は衝撃波の到達により不連続的に $p_{b}$ に上昇する. その後，時刻 $t_{c}$ までの圧縮波により圧力は上昇し， 膨張波により時刻 $t_{e}$ では圧力 $p_{a}$ に戻る. 時刻 $t_{a}$ から時刻 $t_{e}$ にかけて, 衝撃波を伴った圧力波が測定位置を通過 した際のエントロピ変化の式は，次式より与えられる.

$$
\frac{s_{e}-s_{a}}{R}=\ln \left[\left(\frac{T_{e}}{T_{a}}\right)^{\frac{\kappa}{\kappa-1}}\left(\frac{p_{e}}{p_{a}}\right)^{-1}\right] \approx \frac{\kappa}{\kappa-1}\left(\frac{T_{e}}{T_{a}}-1\right)
$$

ここで， $s ， T$ はそれぞれ，エントロピ，温度を示し，添え字は各時刻における状態量を示している．また，Rは 気体定数を， $\kappa$ は比熱比を示す. 圧力波によるエントロピ変化は衝撃波により生じる. 衝撃波による圧力増加の割 合が小さい場合，エントロピ変化は次式で与えられる.

$$
\frac{s_{b}-s_{a}}{R} \approx \frac{\kappa+1}{12 \kappa^{2}}\left(\frac{p_{b}-p_{a}}{p_{a}}\right)^{3}=\frac{\kappa+1}{12 \kappa^{2}} P^{3}
$$

ここで， $P$ は衝撃波の強さである．本研究において計測された最大の衝撃波強さ $P \approx 0.08$ であり，このときの各 近似式の誤差は式 (1) では約 $1.1 \%$, 式 (2) では約 $12.3 \%$ 程度生じる. 式 (1) および式 (2)より, 衝撃波を伴った圧 力波による温度上昇 $\Delta T$ は次式となる。

$$
\Delta T=T_{e}-T_{a}=T_{a}\left(\frac{\kappa^{2}-1}{12 \kappa^{3}}\right) P^{3}
$$

式 (3)より，圧力波による温度上昇は衝撃波の強さ $P$ の 3 乗に比例する.

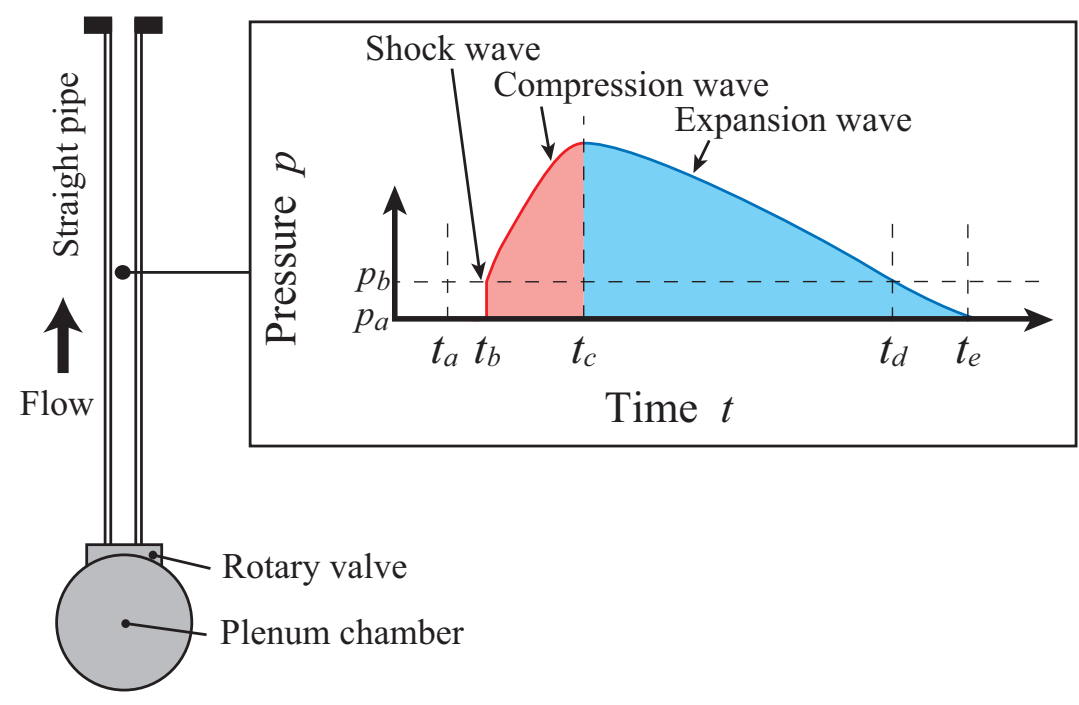

Fig. 5 Typical pressure change in pipe. The arrival of the shock at a station causes the pressure change of $p_{a}$ to $p_{b}$ at $t_{b}$. The pressure comes back to $p_{a}$ by the following pressure wave. 
ニュートンの冷却法則に，ロータリーディスクの開口周期 $\tau$ と, 障害物と脈動流の干渉時間 $\Delta t_{i}$ を加味すると, 障害物への伝熱量を表す式は以下のようになる.

$$
Q=q N A=\frac{\alpha \Delta t_{i}\left(T_{i n}-T_{w}\right) N A}{\tau}=\alpha f N A \Delta t_{i} \Delta T
$$

ここで， $Q$ は伝熱量， $q$ は熱流束， $N$ は障害物の格子数， $A$ は 1 つの格子の面積， $\alpha$ は平均熱伝達率， $T_{i n}$ は管内 を流れる流体の主流温度， $T_{w}$ は障害物壁面温度， $f$ は脈動周波数を示している．また，管内の温度は圧縮波が衝 撃波へと遷移しなければ変化しない.よって，流体の主流温度と障害物壁面との温度差は，式 (3) の衝撃波による 上昇温度 $\Delta T$ とする. 平均熱伝達率 $\alpha$ は, 気体および液体の十分に発達した乱流に適用可能な Dittus-Boelter の式 を用いる (Dittus and Boelter, 1930). レイノルズ数 $R e_{d}$ の適用範囲は $2500<R e_{d}$ である.

\section{4. 実験結果および考察}

\section{$4 \cdot 1$ 管内圧力測定}

図 6 に圧力比 $p_{0} / p_{a t m}=4.0$, ロータリーディスクの回転数 $n=4500 \mathrm{rpm}$ の管内圧力測定の結果を示す. ただし，実 験で使用した圧力変換器の 1 次共振周波数 $40 \mathrm{kHz}$ 以上の周波数帯をローパスフィルタにより除去している. 図の 横軸は測定時間 $t$ とロータリーバルブの開口周期 $\tau$ によって無次元化した無次元時間 $t / \tau$ であり，ロータリーディ スクの断面積変化 2 周期分を示している. また, 縦軸は測定圧力 $p$ と大気圧 $p_{a t m}$ による無次元圧力 $p / p_{a t m}$ である. 図中の最下部の波形は，ロータリーディスクの開口断面積比 $\psi$ の変化を示している. 図の左側に描かれた図は供 試管を示しており，ロータリーディスクから各測定孔と管端部の位置関係を示している。また，障害物を取り付け た位置を明確にするために，障害物の設置位置を示している.

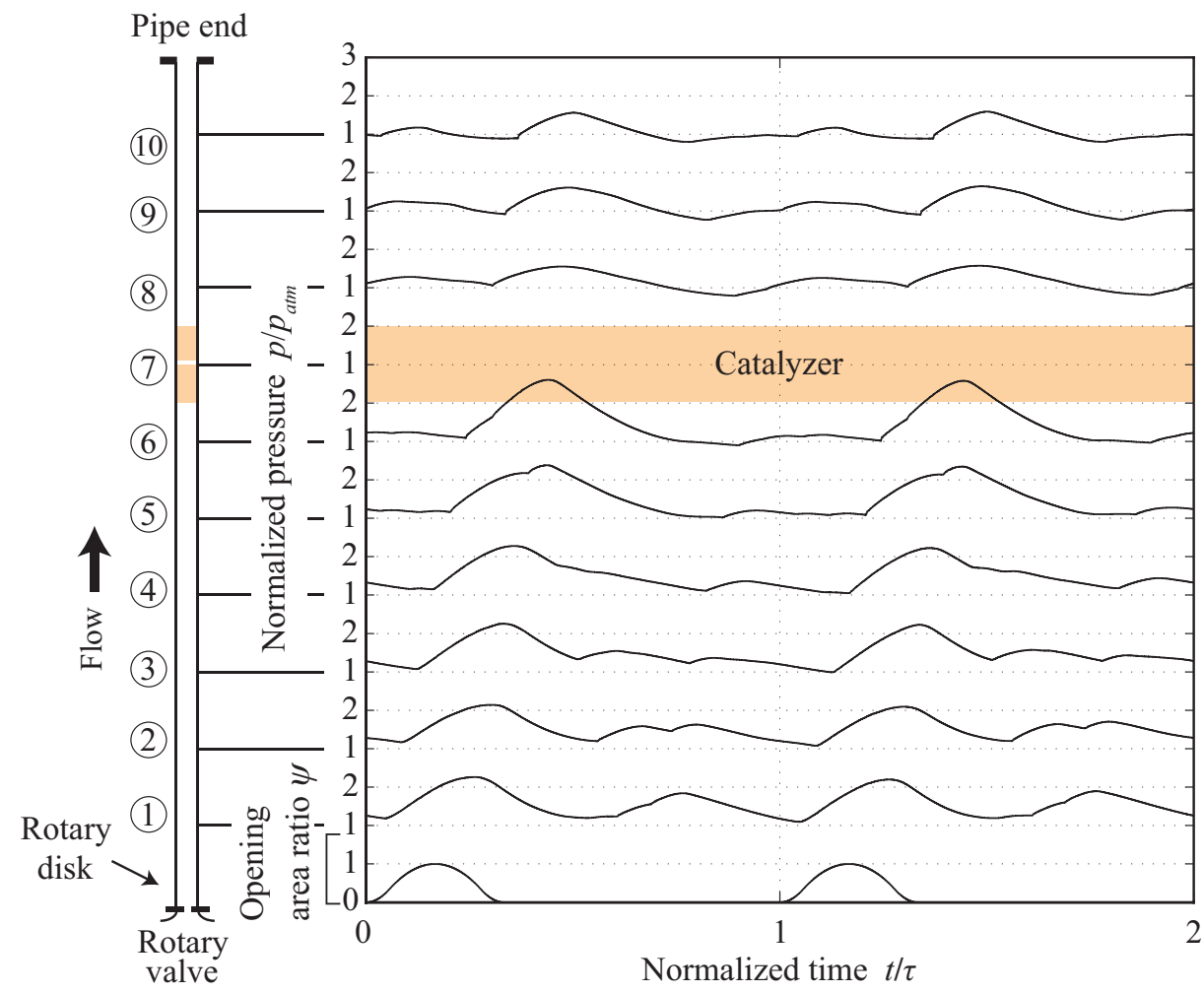

Fig. 6 Pressure histories at $p_{0} / p_{a t m}=4.0$ and $n=4500 \mathrm{rpm}$. The ordinate is the time nodimensionalized by a period of one cycle of the rotary vlave and the abscissa the pressure by the atmospheric pressure. The compression wave is generated by the opening of the rotary valve goes down pipe. The compression wave travelling in the pipe grows strong and becomes weak shock wave. 
罒より，ロータリーディスクの開閉により生じた圧力波が供試管内を上流から下流に向って, 伝ぱする様子が確認 できる。

衝撃波は圧力の不連続面として圧力波形に現れるが，図 6 の圧力履歴より衝撃波を特定することは難しい. そ

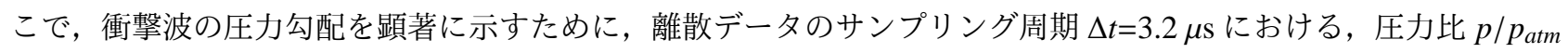
の差分を行った. 本研究では, これを無次元圧力波強さ $I_{p}$ と定義し次式で示す.

$$
I_{p}=\frac{\Delta p}{p_{a t m}}\left(\frac{L}{a \Delta t}\right)
$$

ここで, $\Delta p / p_{a t m}$ は微小時間 $\Delta t$ 間での管内圧力の変化, $a$ は大気温度から算出される音速, $L$ は供試管長さを示し ている. 図 7 に図 6 を無次元圧力波強さに変換した結果を示す. 図より, 各測定孔において, 無次元圧力波強さ が卓越する箇所が現れていることがわかる。これは，圧力波の不連続面を示しており，供試管内を衝撃波が伝ぱ していることを意味している.

ロータリーディスクが 1 周期分開口すると，供試管内には圧縮波と膨張波が一対となった波が下流方向へと伝ぱ する.この圧力波を第 1 圧力波とし, 圧力波の波頭 (衝撃波) を伝ぱ経路1 1 とて実線で示す. また，管端部へと 伝ぱした膨張波が開口端反射し，圧縮波となって上流方向へと伝ぱした波を伝ぱ経路(2)として実線で示す。図 7 の測定孔 6 番から 1 番にかけて，上流へ向って圧縮波が伝ぱしていく様子が確認できる。これは，伝ぱ経路1 9 圧縮波が障害物端面に衝突することで生じた反射波と考えることができる．本研究ではこの圧縮波を第 1 反射波 と定義し，伝ぱ経路(3)として実線で示す。また，図 7 の測定孔 1 番から 10 番にかけて, 再び下流方向へと伝ぱす る圧縮波を確認することができる。この圧縮波は, 第 1 反射波を外挿し点線でつなぐと, 第 1 反射波がロータリー ディスク面で反射し下流方向へ伝ぱした波と考えることができる.よって，本研究ではこの圧縮波を第 2 反射波 と定義し，伝ば経路(4)として実線で示す．ロータリーディスクの回転数が $n=2000 \mathrm{rpm}$ 以上となると，伝ぱ経路(1) の圧縮波は衝撃波へと遷移することが確認された。一方, 伝ぱ経路(2の圧縮波は, 各条件において衝撃波への遷 移は確認できなかった。

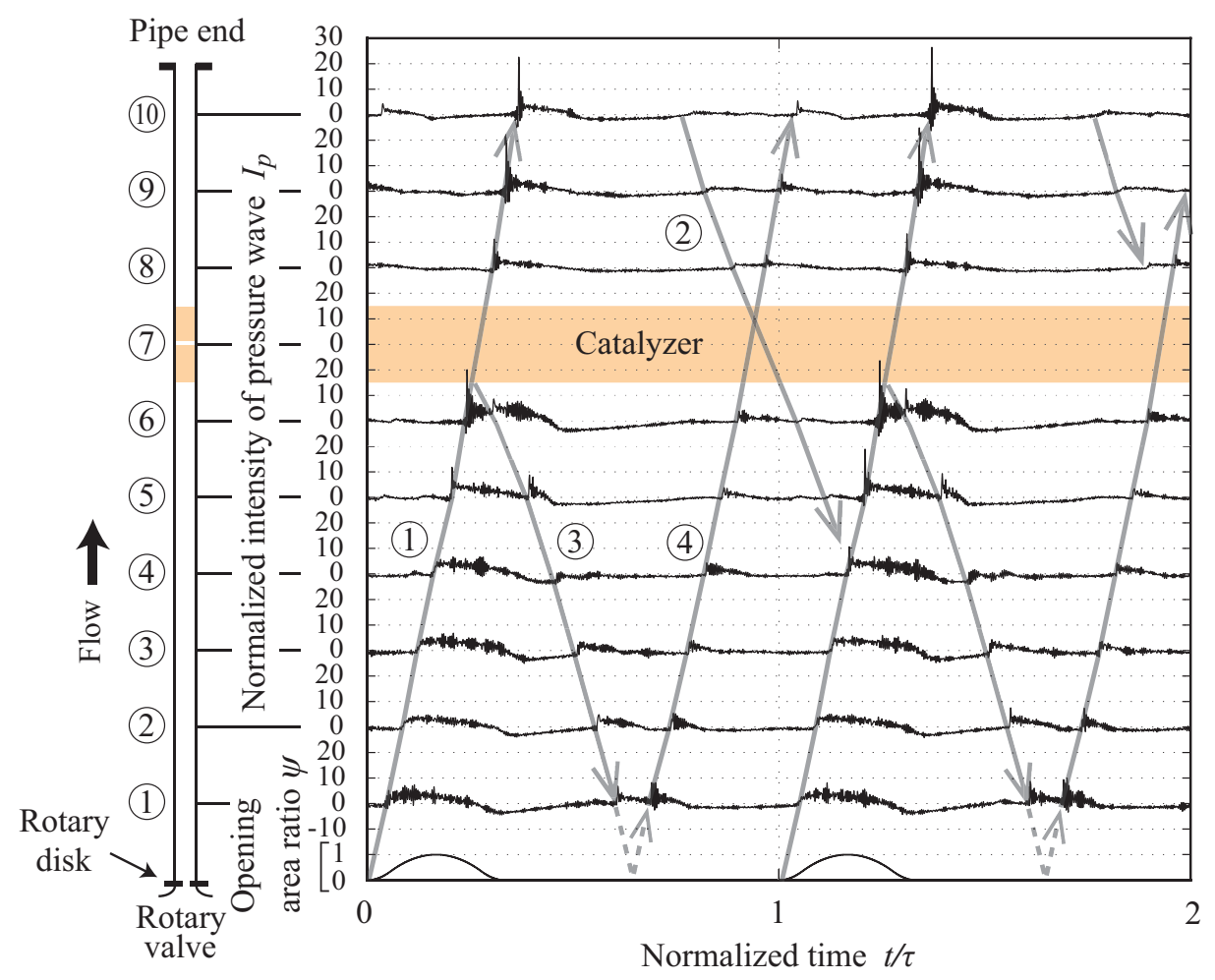

Fig. 7 Wave diagram at $p_{0} / p_{\text {atm }}=4.0$ and $n=4500 \mathrm{rpm}$. The pressure histories shown in Fig. 6 is differentiated with respect to time to obtain the intensity of pressure wave $I_{p}$. 


\section{$4 \cdot 2$ 管内温度測定}

図 8 に管内温度測定の結果を示す. 図の結果は, ロータリーディスクの回転数によるヒステリシス特性を考慮 するため, 回転数を $500 \mathrm{rpm}$ から上昇させ測定を行った結果と, $4500 \mathrm{rpm}$ から減少させ測定を行った結果の平均 值を示している.

ここで, 高圧タンク内圧力が測定孔 6 番の平均圧力まで高圧タンク内圧力から等エントロピー的に膨張した際 の温度を $T_{r e f}$ とする. 縦軸は無次元温度 $\left(T_{7}-T_{r e f}\right) / T_{r e f}$ を示し, 横軸は 4 ストローク内燃機関を想定した脈動周波 数 $f$ を示している. 図 8 において, 圧力比 $p_{0} / p_{a t m}=4.0$ と 3.5 における温度変化は, $f=67 \mathrm{~Hz}$ から $200 \mathrm{~Hz}$ にかけ て無次元温度は約 0.02 から 0.03 減少し, $f=200 \mathrm{~Hz}$ から $600 \mathrm{~Hz}$ の範囲で無次元温度は約 0.04 上昇することが確 認できる. また, 圧力比 $p_{0} / p_{a t m}=3.0$ の温度変化は, $f=67 \mathrm{~Hz}$ から $200 \mathrm{~Hz}$ にかけて約 0.02 減少し, $f=200 \mathrm{~Hz}$ か ら $600 \mathrm{~Hz}$ の範囲で約 0.03 上昇することが確認できた. $f=67 \mathrm{~Hz}$ から $200 \mathrm{~Hz}$ までの減少量は圧力比 $p_{0} / p_{a t m}$ が大 きいほど大きい。これは，管内に生じる波動現象によるものと考えられる.

各圧力比において $f=267 \mathrm{~Hz}$ 以上となると，障害物近傍の温度は上昇する傾向にあることが確認できる. 式 (3) より，供試管内の温度は，管内に衝撃波が形成されることで上昇する．よって，障害物近傍の温度は伝ぱ経路(1) 圧縮波が衝撃波へと遷移したことで，上昇したと考えることができる.

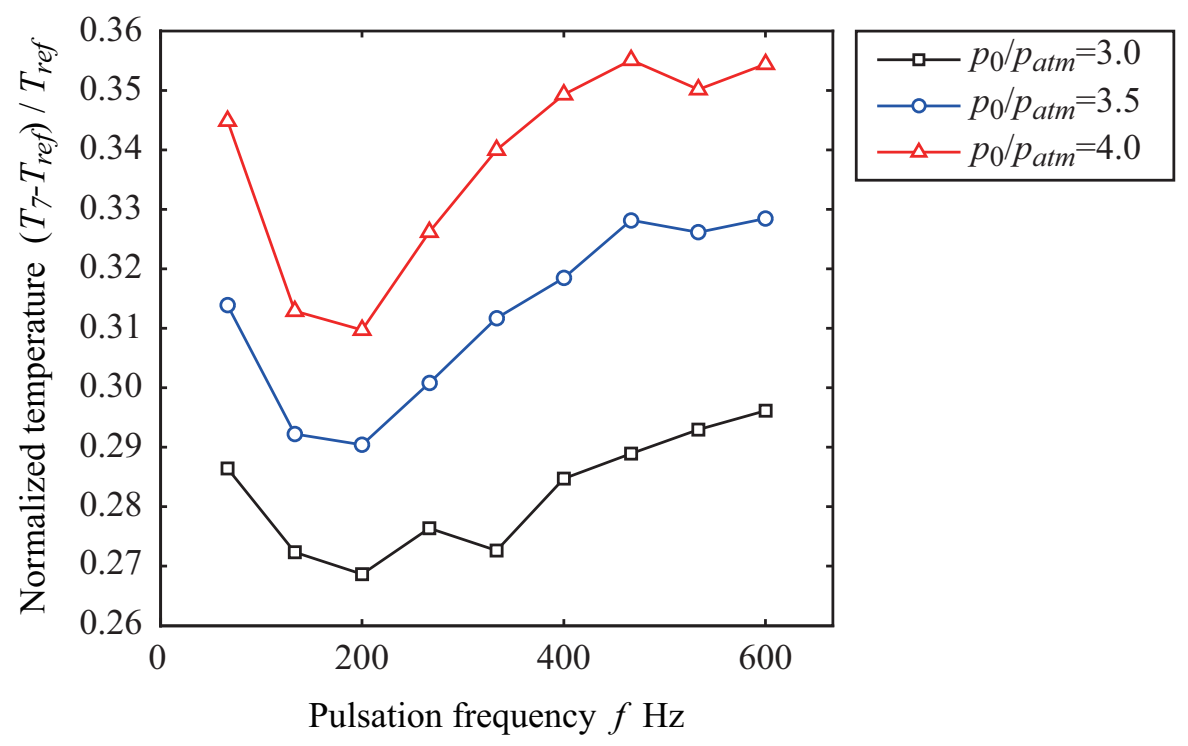

Fig. 8 Variation of normalized temperature with the pulsating frequency $f$. As the pulsating frequency increases, the temperature decreases in the region ranging from $f=67 \mathrm{~Hz}$ to $200 \mathrm{~Hz}$ and gradually increases.

\section{$4 \cdot 3$ 衝撃波による上昇温度の算出}

式 (3) より, 衝撃波による上昇温度は, 衝撃波前後の圧力 $p_{a}$ と $p_{b}$ を供試管内圧力履歴より測定し, 衝撃波の強 さ $P$ を算出することで得ることができる. 本研究では, 20 周期分の衝撃波の強さ $P$ を算出し, この平均值を衝撃 波による上昇温度の算出に用いた。 また，衝撃波前方の初期状態における温度 $T_{a}$ には $T_{r e f}$ を用いた. 各圧力比に おける衝撃波による上昇温度 $\Delta T$ の算出結果を図 9 に示す. 図の横軸は 4 ストローク内燃機関を想定した脈動周 波数 $f$ を示し, 縦軸は衝撃波による上昇温度 $\Delta T$ と温度 $T_{r e f}$ による無次元温度を示している. 図 9 より, 第 1 圧 力波は脈動周波数が増加することで, 無次元温度は増加する傾向にあることがわかる. しかし, 第 2 反射波は第 1 圧力波と比べて極めて小さい值となっており, 第 2 反射波による障害物近傍の温度変化は無視できるほど小さい ことがわかる. また, $f=267 \mathrm{~Hz}$ においては衝撃波強さは非常に微小であるため計算の対象外とした.

ここで, 図 9 の第 1 圧力波による上昇温度と, 図 8 の供試管内温度測定の結果を比較すると, どちらも脈動周 波数の上昇に伴って温度が上昇する傾向にある.これより, 障害物近傍の温度は, 供試管内に衝撃波が形成される 
ことで上昇することがわかる．また，障害物近傍の温度に影響を与える圧力波は，第 1 圧力波のみと考えること ができる.

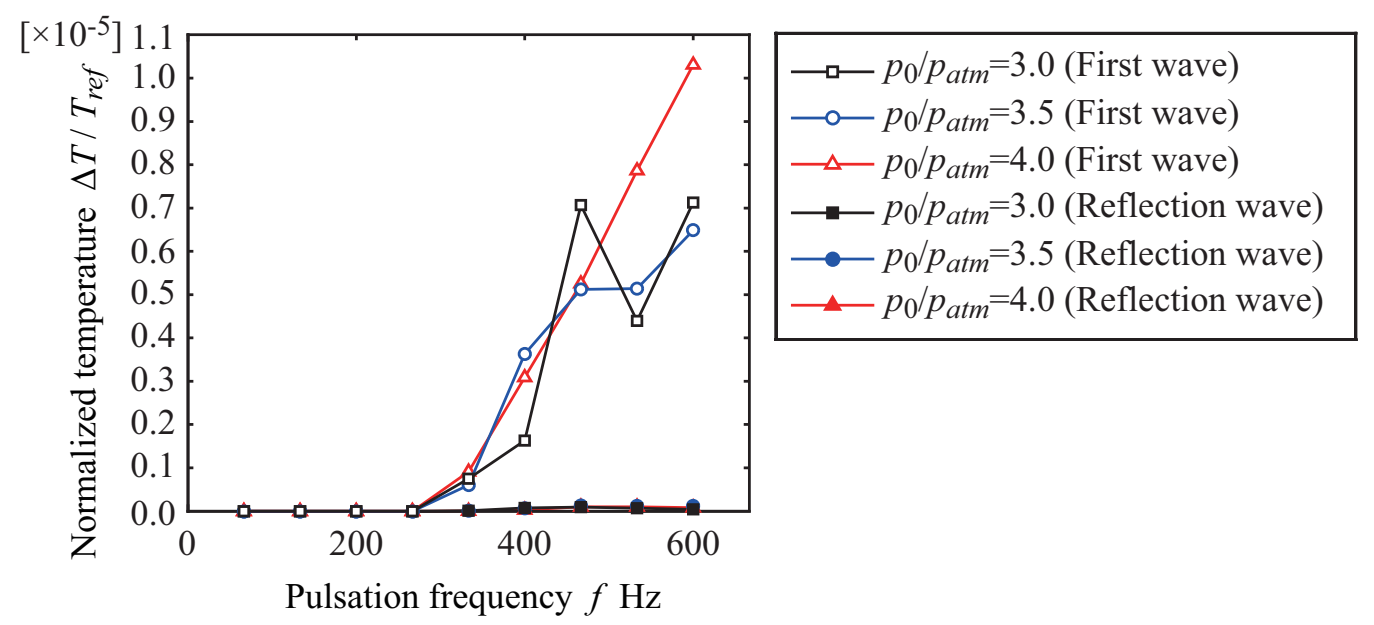

Fig. 9 Temperature rise by the shock wave. The temperature rises by the shock wave in the range from $267 \mathrm{~Hz}$ to $600 \mathrm{~Hz}$, while little rise is by the reflection wave.

\section{$4 \cdot 4$ 平均熱伝達率の算出}

平均熱伝達率 $\alpha$ の算出を行う. 平均熱伝達率の算出のために用いた平均流速 $u$ は式 (6)によって決定した.

$$
u=\frac{l}{2}\left(\frac{1}{t_{1}}-\frac{1}{t_{2}}\right)
$$

ここで, $t_{1}$ は第 1 圧力波の測定孔 5 番から測定孔 6 番までの伝ぱ時間, $t_{2}$ は第 1 反射波の測定孔 6 番から測定孔 5 番までの伝ぱ時間を示す. $l$ は測定孔間の距離を示し $l=100 \mathrm{~mm}$ である. 伝ぱ時間は, 圧力波の 20 周期分の測定 值を用いた。式(6)より算出した平均流速 $u$ の結果を図 10 に示す. 図 10 の横軸は 4 ストローク内燃機関を想定し た脈動周波数 $f$ を示し, 縦軸は平均流速 $u$ を示している. 図 10 より, 圧力比 $p_{0} / p_{a t m}=4.0$ と 3.5 の平均流速 $u$ は, 各回転数において同様の傾向で変化していることがわかる. また, 圧力比 $p_{0} / p_{a t m}=3.0$ は, 脈動周波数 $f=400 \mathrm{~Hz}$ から $467 \mathrm{~Hz}$ において大きく変化していることがわかる. 式(6) より算出した平均流速 $u$ を用いて, レイノルズ数 $R e_{d}$ の算出を行った. その結果, $R e_{d}$ は $1.92 \times 10^{4}$ から $3.44 \times 10^{4}$ の範囲であった. また, 各条件におけるプラン トル数 $P r$ は, Pr=0.70 から 0.73 の範囲となった。これらの結果は, Dittus-Boelter の式を用いるための適用範囲内 である.

図 10 より, Dittus-Boelterの式を用いて熱伝達率を算出した結果を図 11 に示す. 図 11 の横軸は 4 ストローク内 燃機関を想定した脈動周波数 $f$ を示し, 縦軸は平均熱伝達率 $\alpha$ を示している.

\section{5 障害物の加熱}

式 (4) より, 熱流束 $q$ の算出を行う.ここで, 干渉時間 $\Delta t_{i}$ を, 各回転数におけるロータリーディスクの半周期 あたりの開口時間とする. また，ディスク上の孔が開口している時間は，その $1 / 3$ にある.よって, 熱流束 $q$ は 式 (7)のように整理することができる.

$$
q=\alpha f \frac{1}{3 f} \Delta T=\frac{1}{3} \alpha \Delta T
$$


熱流束 $q$ の算出結果を図 12 に示す. 算出には, 図 9 と図 11 の各条件における值を用いた. 図 12 の横軸は 4 スト ローク内燃機関を想定した脈動周波数 $f$ を示している. 圧力比 $p_{0} / p_{a t m}=4.0$ と 3.5 において, 脈動周波数 $f$ が上昇 することで, 熱流束 $q$ も上昇する傾向を示している. 圧力比 $p_{0} / p_{a t m}=3.0$ の条件においても, 脈動周波数 $f$ が上昇 することで, 熱流束 $q$ は上昇する傾向を示したが, 脈動周波数 $f=467 \mathrm{~Hz}$ において $q=0.43 \mathrm{~W} / \mathrm{K} \cdot \mathrm{m}^{2}$ と高い值を示 した.これは, 圧力比 $p_{0} / p_{a t m}=3.0$ の条件の $f=467 \mathrm{~Hz}$ において, 管内流体の平均流速 $u$ が大きく, 平均熱伝達率 $\alpha$ が大きくなるためだと考えられる.

平均熱伝達率 $\alpha$ は脈動周波数 $f$ の上昇に伴う変化が見られない．よって，障害物の温度に影響を与える排気脈 動流の因子は, 図 9 の衝撃波による上昇温度 $\Delta T$ であることが確認できる. また，上昇温度 $\Delta T$ は衝撃波の強さ $P$ の関数であり, 各条件における平均熱伝達率 $\alpha$ と初期状態における温度 $T_{r e f}$ が既知であるとすると, 脈動流から 障害物への熱流束は衝撃波前後の圧力を測定することで，容易に算出することができる.

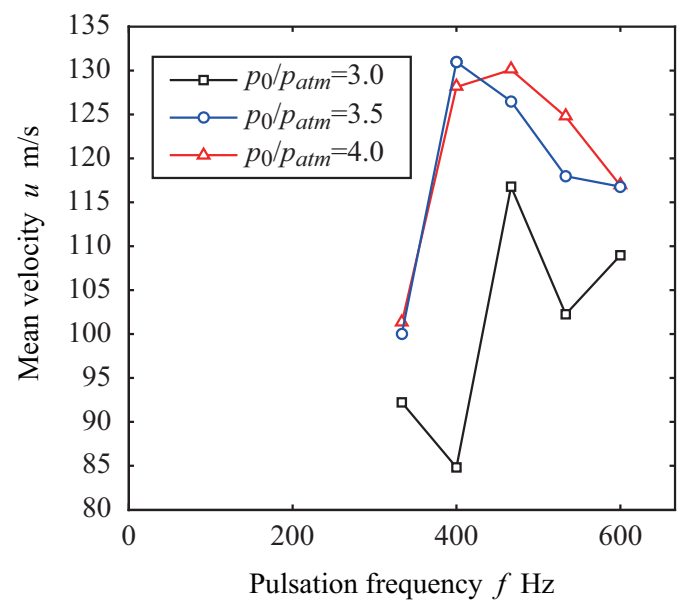

Fig. 10 Variation of mean velocity with pulsating frequency. The mean velocity of flow on which the shock approaches the obstacle is estimated using Eq.6.

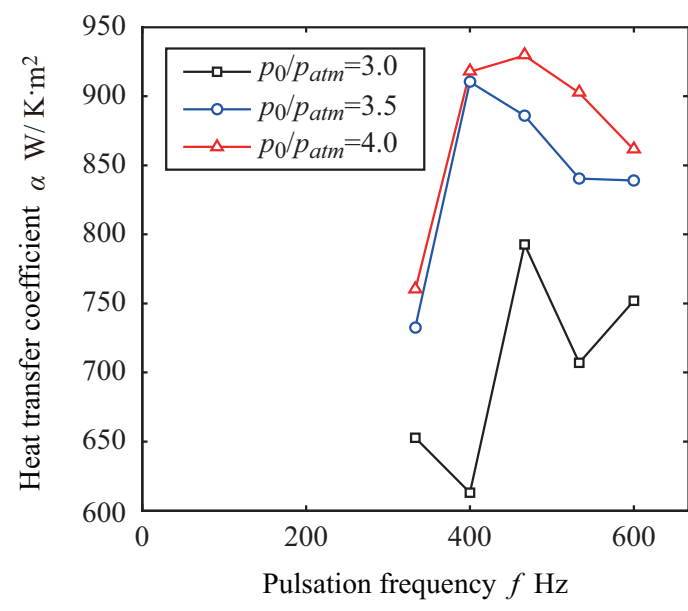

Fig. 11 Variation of average heat transfer coefficient with pulsating frequency. Average heat transfer coefficient is evaluated using Dittus-Boelter's equation.

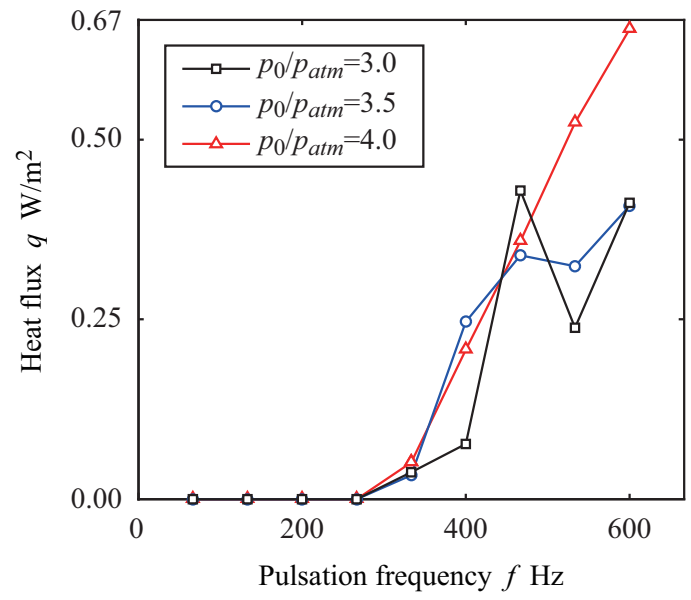

Fig. 12 Heat flux from pulsating flow to obstacle. The heat flux is evaluated under the assumption that the period of time in which the flow interacts with the obstacle is equal to open duration of the rotary valve. The heat flux rises with increase in the pulsating frequency from $267 \mathrm{rpm}$. 


\section{5. 結 論}

本研究では, 自動車等の排気ガス規制および環境問題の対策として, 自動車触媒の温度による浄化特性に着目し た．内燃機関の排気系を極めて単純化したモデル内に触媒を模擬した障害物を設置し，管内圧力測定と管内温度測 定を行い，脈動流が障害物の温度にどのような影響をもたらすかを議論した。その結果，以下の結論が得られた。

1. 供試管内を伝ぱする圧力波は高い脈動周波数において，障害物と干渉する前に圧縮波の一部は衝撃波へと遷 移する。

2. 脈動周波数が上昇すると衝撃波の強さは大きくなり, 障害物近傍の温度は上昇する傾向をみせる.

3. 障害物を設置することで生じる反射波は，ロータリーディスク面で再び反射し障害物と干渉するが，障害物 近傍の温度に与える影響は極めて低い。

4. 脈動流から障害物への熱流束は，衝撃波の強さが大きくなることでその 3 乗に比例し上昇する.

本研究の結果を実機に適応した場合，衝撃波による温度上昇効果は $8000 \mathrm{rpm}$ 以上の高回転数域で現れる.しか しながら，一般的に衝撃波の強さは，下流に進むにつれて大きくなるため，障害物の位置を下流に移動すること により，比較的低回転数域でも同様の効果が期待される.

\section{文献}

馬場直樹，大澤克幸，飯田清三，石田忍，自動車用排気触媒の昇温解析，日本機械学会論文集 B 編，Vol.61，No.590 (1995), pp.224-230.

Dittus, F. W. and Boelter, L. M. K., Heat transfer in automobile radiators of the tubular type, University of california publications in engineering, Vol.2, No.13 (1930), pp.443-461.

Endo, M. and Iwamoto, J., A numerical study of pulsating pipe flow with and without a nozzle, SAE transactions 900678 (1991).

古濱庄一, 内燃機関 (2011), pp.170-171, 東京電機大学出版局.

平田勝哉, 太田光彦, 小田良治, 谷川博哉, 舟木治郎, 高効率自動車用触媒コンバータの為の新しいディフュー ザ，日本機械学会論文集 B 編，Vol.73，No.728 (2007)，pp.88-93.

石谷博美, 大西宏征，常本秀幸，山田貴延，ディーゼル機関の軽負荷領域における触媒活性化のための排気温度 上昇システム, 日本機械学会論文集 B 編, Vol.71, No.705 (2005), pp.237-242.

金崎雅博, 大林茂, 中橋和博, 自動車エンジン排気系形状の多目的最適化, 日本機械学会論文集 B 編, Vol.67, No.663 (2001), pp.114-121.

木村敦典, 岩本順二郎, 高速脈動噴流から生じる騷音に関する研究, 日本機械学会論文集 B 編, Vol.67, No.664 (2001), pp.57-64.

\section{References}

Baba, N., Ohsawa, K., Iida, K. and Ishida, S., Analysis of transient thermal characteristics of automobile catalytic converters, Transactions of the Japan Society of Mechanical Engineers, Series B, Vol.61, No.590 (1995), pp.224230 (in Japanese).

Dittus, F. W. and Boelter, L. M. K., Heat transfer in automobile radiators of the tubular type, University of california publications in engineering, Vol.2, No.13 (1930), pp.443-461.

Endo, M. and Iwamoto, J., A numerical study of pulsating pipe flow with and without a nozzle, SAE transactions 900678 (1991).

Furuhama, S., Nainenkikan (2011), pp.170-171, Tokyo Denki University Press (in Japanese).

Hirata, K., Ota, M., Oda, R., Tanigawa, H. and Funaki, J., On a novel diffuser for efficient automotive catalytic converters, Transactions of the Japan Society of Mechanical Engineers, Series B, Vol.73, No.728 (2007), pp.88-93 (in Japanese). 
Ishitani, H., Oonishi, H., Tsunemoto, H. and Yamada, T., System for increasing exhaust gas temperature for catalyst activation at light load condition in diesel engines, Transactions of the Japan Society of Mechanical Engineers, Series B, Vol.71, No.705 (2005), pp.237-242 (in Japanese).

Kanazaki, M., Obayashi, S. and Nakahashi, K., Design optimization of exhaust manifold for a car engine using MOGA, Transactions of the Japan Society of Mechanical Engineers, Series B, Vol.67, No.663 (2001), pp.114-121 (in Japanese).

Kimura, A. and Iwamoto, J., A study on generation of noise of high-speed pulsating jet, Transactions of the Japan Society of Mechanical Engineers, Series B, Vol.67, No.664 (2001), pp.57-64 (in Japanese). 